\title{
Traditional Building Materials as a Sustainable Resource and Material for Low Cost Housing in Nigeria: Advantages, Challenges and the Way Forward
}

\author{
Prof. Ikechukwu Onyegiri ${ }^{1}$ and Iwuagwu Ben Ugochukwu ${ }^{2}$
}

\begin{abstract}
Traditional building materials are resources that are found readily in large quantity across Nigeria. The availability may largely be dependent on geographical location of the area as well as the chemical and physical components of such materials. The paper critically appraises some major local building material available in Nigeria such as adobe, bamboo, thatch, stones, timber, coconut tree, grasses etcetera. These materials are cheap relative to the imported materials from outside the country. The purpose of this paper was to examine the major advantages, challenges and the way forward for traditional building materials in increasing low cost housing supply and affordability in Nigeria. The study found promotion of cultural heritage, availability and affordability of the materials, energy efficiency, reusability, biodegradability among others as the major advantages of traditional building materials. However, acceptability, durability, deforestation, low strength, frequent maintenance, among other issues were found to be the major challenges associated with houses built with traditional building materials. Recommendation for adoption and improvement of the locally available materials for building houses are made. This paper contributes to the body of knowledge in the area of traditional building materials in Nigeria and Africa at large.
\end{abstract}

Keywords - Traditional building materials, sustainability, affordability, traditional architecture.

\section{INTRODUCTION}

$\coprod_{\mathrm{p}}^{\mathrm{T}}$ $\mathrm{T}$ has become increasingly glaring that most of the urban population live in dehumanising housing environment while those that have access to average housing do so at abnormal cost (Olugbenga, 2001). In developing countries like Nigeria, a home of one's own represents a precious refuge. Literature on housing in developing countries often show that housing ranks above education and health services as a priority. Thus households in developing countries value homeownership more than households in advanced industrialized countries. In fact in most developing nations when a family does not have a house they can call their own, that family is regarded as the poorest of the poor. Provision of affordable housing for the citizenry has remained the principal focus of every successive government in Nigeria.

\footnotetext{
${ }^{1}$ Department of Architecture, Imo State University Nigeria.

${ }^{2}$ Department of Architecture, Abia State Polytechnic, Nigeria..
}

This is because of the pivotal roles played by housing in national development and growth on one hand and its being a necessity in the life of the people, on the other hand.

Sustainable construction requires a critical review of prevailing practices, techniques and sources for raw materials. The rising cost of building is a source of concern to most governments in the world, especially in the developing countries. One possible cause is the rising cost of building materials since greater percentage of the cost of buildings is incurred on the materials (Yalley \& Kwan, 2008). In the case of Africa, for example, there is an acute lack of affordable houses which is largely due to the high cost of the conventionally processed construction materials such as steel and Portland cement. The desire generated for these materials has a negative impact, leading to reduced value and perceived inappropriateness of locally available materials. Ideally, building materials for low-cost housing should be produced from locally available raw materials. Furthermore, it would be best if these raw materials were abundantly available or they should be renewable in nature (RICS, 2008). Over- reliance on foreign and imported building materials is not the only contributing factor of rising cost of buildings but also the transportation from urban areas to rural areas and vice versa especially in the face of this current fuel scarcity and hike in Nigeria.

The Nigeria housing question is primarily that of a crisis situation, manifesting and expressing itself in qualitative and quantitative forms. Although the present housing difficulty in Nigeria arises not necessarily because of poverty, but because of the absence of an effective administrative arm to mobilize and organise the country's natural resources, human, industrial, etc, for housing and urban development. However, the problem of poor co-ordination and ineffectiveness of some public housing agencies in Nigeria is in most cases responsible for the failure of certain laudable housing policies and programmes.

Housing delivery is a highly contentious and politicised issue that is of great concern to administrators, scholars and the public in Nigeria. In the last few decades, the influx of people into urban areas, the natural population increase and inadequate responses by the government have contributed to the worsening housing situation in the country (Afolabi \& 
Oamide 2012). These problems have become more critical in the cities, where huge housing supply deficits, dilapidated housing conditions, high cost of housing as well as proliferation of slums and squatter settlements exist (Ajanlekoko, 2002, Akeju, 2007). As a result, a large majority of urban residents, particularly the low-income earners who constitute about $50 \%$ of Nigeria's 160 million people are forced to live in conditions that constitute an affront to human dignity (Alemayehu, 1999).

In many developing countries, including Nigeria, housing crisis is escalating unabated despite a number of new policies, programs and strategies being engaged in by public and private sectors in addressing this problem. Government has recognized that the majority of those in need of housing in many less-developed nations in Africa, Asia and South America are in the low income cadre and that some require special housing programs to be able to live in decent housing. Since market solutions and funds may not be suitable for housing this category of people and in view of the vital role housing plays in the socio-economic and political development of any nation; governments in these countries have over the years been engaged in public housing provision. In Nigeria however, from the debut efforts of the Lagos Executive Development Board (LEDB) in 1928 to date, public housing provision in this country has continued to lag behind the demand for housing, as almost $90 \%$ of the nation's housing stock is provided by the informal sector.

The paper appraises some major local building material available in Nigeria examine the major advantages, challenges and the way forward for traditional building materials in increasing low cost housing supply and affordability in Nigeria and concludes by recommending adoption and improvement of the locally available building materials for building construction in Nigeria.

\section{II.HOUSING NEED IN NIGERIA}

Various governments in Nigeria have often expressed interest in housing provision for the masses. A review of past efforts indicates that the achievement level of the various national housing programmes was low. Rapid urban growth associated with accelerated tempo of socio-economic development has seriously aggravated the shortage of dwelling units, resulting in overcrowding, high rent, slum and squatter settlements which are visible features of urban centres throughout the country. Estimate and indicator of the magnitude of housing shortage vary. In summary, they all indicate massive shortages in total housing required. The total housing needs of the country in urban and rural areas were put to some 8 million units by the year 2000 by Federal Ministry of Works and Housing, and 12-14 million units in 2007 (Akeju, 2007). A more recent estimate puts the figure even higher at 16-17 million units (Aribigbola and Iranlowo, 2012).

At an average cost of 2.5 million naira per housing unit, Nigeria will require 35 trillion Naira to fund the housing deficit of 14 million housing units (Onyike, 2007). A recent study based on the salary structure of public servants in
Nigeria showed that no public servant in Nigeria below salary grade level 13 in the federal civil service and salary grade level 16 in the Imo state civil service can afford a property costing $\mathrm{N} 4.75 \mathrm{~m}$ on a 25 years mortgage at 6 percent if he devotes 50 percent of his salary per annum to housing (Onyike, 2007). At 18 percent mortgage rate, only a federal permanent secretary or his equivalent on grade level 17 can afford the same house. This shows that in the absence of some assistance and affordable strategies, adequate housing is unaffordable to most law abiding Nigerians.

\section{LOCAL BUILding MATERIALS/AFRICAN ARCHITECTURE AS Alternative}

The architecture of Africa has been seen and labelled international. The definition of architecture as the art and science of building has over the years seen a lot of reforms to include usability, acceptability and comfortability. That African architecture does not have documented scientific approach to its design and construction does not mean that it fails to satisfy these conditions. A building system proven to satisfy thermal comfort, aesthetics and sustainability and being a major part of the daily life of its occupants cannot be anything short of architecture. African traditional architecture is essentially sustainable and had evolved culturally to suit the people. Usually, earth, timber, straw, stone/rock and thatch were constructed together with the simplest of tools and methods to build simple, liveable dwellings. Although globalization has relegated them as being 'primitive', this 'primitive' classification comes partially from the building materials and their relatively low technological uses when compared to present day western (Architectural) construction techniques which result in skyscrapers. Present interpretations of sustainability have given them a new status as likely technologies for the contemporary world. Along with the others that have been re-devised, earth has of late gained acknowledgement as a suitable technology for contemporary buildings. Africa as a tropical continent between the Atlantic (west) and Indian (east) oceans has an over 5000 year's old recorded history that shows buildings and monuments made of numerous natural materials available in abundance in its geographical landscape. Looking into history particularly on the African continent; Egypt, Nigeria, Kenya, Mali etc, we hear and sometimes carry out studies on the New Gourna Village by Hassan Fathi, the Ancient Kano and Zaria cities by the indigenous craftsmen, the Great Mosque of Djenné directed by Ismaila Traoré, and a few other examples. These buildings have lasted for over one hundred (100) years at the least and have proved themselves to be outstanding works of architecture that have not only stood the taste of time but are cheap, comfortable with little or no carbon footprint. Having such immense potential, traditional African architecture particularly building with adobe bricks is worth looking into.

Its indigenous architectural practice had been shaped by ideologies of sustainability though according to Opaluwa, Paul, and Osasona (2012) it was done in ignorance. Developed from naturally existing materials and cyclical possibilities of their regeneration, they impacted on the 
judicious use of earth's resources in the construction of its villages and hamlets, the cities and urban centres as well as the temples, tombs, monuments and religious edifices. Predictably, earth/mud/adobe has been one of its most important and chief building material combined with timber (mostly from palm trunks), palm/coconut/grass thatch and straw bales as roofing; all materials abundantly available in the settlements. In entirety, Africa's traditional architecture made certain that its use of the resources neither diminished their availability, nor adversely affected the ecological balance upon which it relied on as an agrarian society.

The introduction of modern technologies such as the concrete blocks and slabs during the industrial periods had relegated traditional components and methods to the background and it became the goal of those in the wattleand- daub houses to remake them with the new trend material; concrete blocks, in spite of the obvious truth that they did not present the same kind of thermal comfort. The native dwellers thus replaced their comfortable, low- cost and sustainable houses with the modern opposite which were the current fashion and expressed advancement, modernity and a show of affluence and status in the social hierarchy. Recently, amidst these unsustainable practices earth construction has received greater attention as a building material that can be very affordable and still deliver the same modern needs (Dayaratne , 2011).

\section{A Case of Selected Traditional Building}

Straw/Thatch Architecture: In contrast to some other materials which are not easily renewed, straw/thatch is a byproduct of grown plants hence, a cultivated material. Large quantities of this material could be sourced from the immediate surrounding as the villagers cultivate much of the straw as cereals in their farms which in turn provide them a building material. Straw has in most case being used with adobe bricks or masonry walls or singularly. Even today nomad tribes within Africa still use this form of construction. Straw construction uses matted or baled straw from wheat, oats, barley, rye, rice and others as walls or covered by earthen or lime stucco. Straw bale are traditionally a waste product; it is the dry plant material or stalk left in the field after a plant has matured and harvested.

Adobe Architecture: the cultural practice of the rural people indicates that adobe surely has been one of the most common and abundantly obtainable materials that influenced and sustained the rural villages in Africa. Local earth technologies of Africa have spanned form the employment of raw-earth, to refined earth brick. Generally employed was wattle-and-daub earth technology; a method that uses solid wooden post frame which is first made then filled with adobe balls to create a wall. Most often, the African builders construct the walls of their building layer by layer using the mud bricks and a slurry mixture of earth as the mortar. Once the wall dries up and binds into a monolithic structure, a dense mud plastic plaster strengthen with various additives depending on the people's culture (cow dung, goat dung, beaten straw, animal hair, animal skin fat) will be spread on by hands to smoothen the facade. The materials having being gotten from the environment certainly made it a highly sustainable practice that utilised small amount of energy and did not generate any greenhouse gas or harmful waste. As soon as it is plastered and properly covered with overhanging roofs, these earth buildings were structurally firm, environmentally sound and could exist for years as long as the day to day maintenance was adhered to.

Bamboo: Bamboo is one of the oldest traditional building materials used by mankind. When you're considering potential building materials for home construction as a society we tend to focus on two or three commonly utilized and widely accepted building materials: wood, stone or concrete. Uses for bamboo can also include building construction, both in exterior and interior design elements. Unlike wood, bamboo (a member of the grass family) regenerates very quickly. It is, in-fact, one of the fastest growing plants in the world, with the fastest growth rate reaching $100 \mathrm{~cm}$ in a $24-\mathrm{hr}$ period (Farrelly, 1984). In contrast to tree harvesting, there is simply no comparison to the replenishment rate of growing bamboo. Bamboo can be harvested every three to six years for construction purposes (depending on the species); whereas trees range from 25 years (for softwoods) to 50 years (for hardwoods). Major Advantages of Bamboo include: Strength and Durability; Affordability.

Grasses: Grasses were found in the Middle Belt and Northern region abundantly for the purpose of construction in Nigerian Traditional Architecture. The type of grasses available in a locality depends on the climatic region, vegetation and closeness to water source. Toward the South of the Middle Belt region, elephant grasses were common; even in the Northern part of South Western, Mid - Western and Eastern region; while in the Middle Belt and Northern region, spare grasses were very common (Jolaoso, 2001; Bourne, 1981, Denyer, 1978).

Wild Coconut Tree: This fibrous tree is found mainly in the savannah region (Middle Belt) of Nigeria. It produced good structural member for roof, wall, lintel, ceiling and bridges construction. It is also used as overlay for toilet pits. Unlike timber, it is a termite resistance structural and don't easily decay unless subjected to long period of dampness (Dmochowski, 1990).

\section{V.AdVANTAGES OF TRADITIONAL AFRICAN BUILDING MATERIALS}

Availability. Traditional African building materials are abundant in nature. These materials include earth, stone, thatch, coconut fibre etc. for example earth building technology involves the use of laterite and loamy soil that exist in abundant supply in all part of the continent. Earth has been used by our fathers and fore-fathers to erect buildings, sometimes up to two storeys high without addition of any other reinforcing materials and most of them are still standing till date.

Affordability. The major reason for high cost of imported building materials in Africa includes high cost of importation 
and general inflation. Because of high cost of these imported building materials, the low income earners find it difficult to construct their own houses or even rent a decent house. The availability of these local building materials makes the price affordable and gives the low income earners the opportunity to construct their own houses.

Energy Efficiency. Environmental protective measures ensure reduction of operational energy in construction. Studies according to Iwuagwu and Azubuine (2015) reveal that the building sectors consume more than one third of the world's energy, and contribute to global warming. A typical traditional building of earth emits fewer greenhouse gases, consumes less energy, and maintains a high level of internal thermal comfort, regardless of prevailing solar radiation outside (Iwuagwu and Azubuine, 2015).

Ozone Friendly. The built environment contributes ultimately to global warming by its high rates of greenhouse gases emission through energy use (for cooling, heating, and lighting) and construction. Local building materials projects a possibility of total reduction to a near zero carbon emission of buildings. Local building materials are eco-friendly, climate responsive and organic protective measures to safeguard and as well minimize environmental impact. The thermal insulation, energy saving, etcetera of local building materials reduces negative environmental impact. The proximity of materials saves cost and reduces pollution by fuel burning through transportation.

Reusability: Reusability is a function of the age and durability of a material. Very durable materials may have many useful years of service left when the building in which they are installed is decommissioned, and may be easily extracted and reinstalled in a new site. Windows and doors, even brick can be successfully reused. Timber from old barns has become fashionable as a reclaimed material for new construction.

Biodegradability: The biodegradability of a material refers to its potential to naturally decompose when discarded. Organic materials can return to the earth rapidly, while others, like steel, take a long time. An important consideration is whether the material in question will produce hazardous materials as it decomposes, either alone or in combination with other substances. Traditional African building materials exhibit this characteristic, example include, earth, thatch, bamboo, timber etcetera.

\section{Challenges of Traditional African Architecture AND THEIR BUILDING MATERIALS}

Acceptability: The future of any Architecture depends on the extent to which it is acceptable to the people for whom it is intended. The notion that buildings of traditional materials are substandard is the main obstacle to the development of an authentic African Architecture that is truly indigenous to the people. Perhaps issue of acceptability has brought destruction of traditional values and their replacement with alien ones.

Durability/ Low Strength: The highest problem of houses built with traditional African building materials was the low strength of the houses, implying that the locally available materials have strength that is below expectation when compared with strength of the houses built with conventional materials such as cement, concrete, steel, among others. The strength of every house is important because it determines the durability and security of the house. This is consistent with the view of Venkatarama and Prasanna (2009) that one of the drawbacks for using earth alone as a material for construction is its durability which is strongly related to its compressive strength. Riza et al. (2011) further explained that most soil in their natural condition lack the strength, stability and durability required for building construction. The above indicates that the local materials for building houses lack the desired strength and improvement of their strength properties would be beneficial to the users.

Building Tall: The nature and strength of these traditional building materials make it impossible for building tall. They encourage low rise buildings leading to over use of land. Millions of acres of land in Africa have buildings constructed on them. For instance, spread of buildings require the construction of new roads, drainage, utility poles, and other infrastructure, which lead to, habitat destruction, land disturbance and erosion, environmental pollution, global warming among other.

Deforestation: the building materials sources in Africa contribute to prevailing problem of deforestation on the continent. When timber for construction is harvested, in many cases, replacement trees are not planted, if replanted, the rate of replacement is far lower than the rate of consumption.

Civilization: Local and indigenous cultures have practiced sustainable resource use due to their practical experience and human dependency on earth's life support systems. Traditional communities integrated buildings into the natural environment in terms of adequate use of cost effective and easily assessable local building material for construction and maintenance. However, importation and the use of imported building materials has put the African traditional and sustainable way of building and construction processes in danger, thus relegating our architecture

Frequent Maintainance: Frequent maintenance of houses built with local materials especially earth, is another challenge facing African architecture. According to Rumana (2007) there is high maintenance requirement of earthen plinth and walls which are often plastered, especially during the wet season. This is due to the low strength of the materials that make it a requirement for the frequent maintenance in order to keep the building is good condition for use. If the houses built with local materials are not maintained regularly, they will deteriorate in some few years after their construction due to their vulnerability to weather such as rain and storm.

\section{THE WAY FORWARD FOR TRADITIONAL ARCHITECTURE AND THEIR MATERIALS}

Re-Engineering of traditional African Building Materials: Traditional African building materials should be 
re-engineered to suit the present need of building materials. Like the compressed earth block (CEB), this is an emerging alternative to adobe blocks and wattle and daub construction. Compressed earth blocks are a creative, re-engineering of the adobe brick. Unlike the native adobe block, which is a mixture of soil, water and distinct cultural additives moulded to desired shape with the hand, the compressed earth block is supplemented in very small amounts (in most cases less than $10 \%$ ) with either cement or lime component in its blending process. The blend is not worked to achieve a plastic state, but simply blended until the cement/lime and soil are thoroughly mixed. Afterwards, the mixture either machine pressed or placed in a mould and compacted with a high level of pressure applied through a hand- operated machine. After aeration, the CEBs gain a high compressive strength appropriate generally for three floors constructions but higher potentials can also be attained for up to five floors constructions [Maini, 1999]. CEB construction is more durable than wattle and daub, and is also accepted as a more refined construction method than wattle and daub.

Combination with Modern Building Materials: there should be combination of conventional building materials with traditional African building materials to add to their strength and durability. One of the disadvantages is strength, but that notwithstanding, in high rise buildings CEB could be used for the walling system not minding the height of the building while the conventional materials would be used for the foundation, reinforcement etcetera.

Government Encouragement: Government should encourage the use of local building materials by using them in government projects all over Africa. Traditional African building materials should be included in building code of various countries in Africa, as building materials. In every construction there should be a little destruction, efforts should be made to plant more trees and make sure natural resources are not being used more than it generate. As our natural resources are quickly depleting and our homes and vehicles are damaging our planet more than ever, it's time for a change. We should detach ourselves from the notion that local building materials are low-grade material. Considering the depletion of the ozone layer, high energy consumption by buildings we will realize that local building materials are not only the past, but the future of our society and one should take into consideration the benefits that they offer.

\section{RECOMMENDATION}

The following recommendations will be of great help:

1. Governments should encourage the use of locally available materials for building houses so as to promote their culture and attracts tourists in the country for economic growth.

2. Because of availability of these traditional building materials in Nigeria, governments should encourage the use of local materials in constructing houses in order to reduce the housing deficit and also produce affordable housing.

3. It is therefore important for people living in hot weather like Sub-Sahara African to adopt the use of local materials for their housing in order to reduce the effect of heat from the hot weather on their health and the amount of energy required to fan and air-condition their rooms for comfort.

4. Future researchers should consider researching into how to reinforce the mechanical and durability properties of the local materials with industrial and agricultural wastes or other conventional materials to ensure long lasting of the houses built with local materials.

5. Government should encourage the local building materials industries by creating conducive atmosphere for operation right from the registration process to grant as well as granting of holiday tax in some cases when it is highly needed.

6. Some planning authorities who hitherto restrict people from using local building materials in the cities should be made to relax their stringent condition thereby encouraging developer to commence their development with the use of local building materials.

7. The curriculum of technological, architecture, engineering institutions should be reviewed to reflect the study of the application of locally sourced building materials and government, Architects, Engineers and other related professionals should lay examples by building their respective houses with these materials as a substitute to the conventional ones.

\section{CONCLUSION}

The purpose of this study was to examine the major advantages, challenges and the way forward for traditional building materials in increasing low cost housing supply and affordability in Nigeria. The study found promotion of cultural heritage, availability and affordability of the materials, energy efficiency, reusability, biodegradability among others as the major advantages of traditional building materials. On the other hand, acceptability, durability, deforestation, low strength, frequent maintenance, among other issues were found to be the major challenges associated with houses built with traditional building materials. Recommendation for adoption and improvement of the traditional local building materials for building construction are made. However, when the solutions being recommended are implemented the country's housing shortage and housing affordability issues will be minimise in view of the abundance of wealth and manpower resources vested on the country.

\section{REFERENCES}

[1] Afolabi, A and Oamide, I. (2012). Site and services as a strategy for achieving adequate housing in Nigeria in the $21^{\text {st }}$ century. International Journal of Humanities and Social Science 2 (2), 126-132.

[2] Ajanlekoko, J. (2002). Appraisal of the National Housing Policy. Housing Today 1 (6):13- 20.

[3] Akeju, A. (2007). Challenges to providing affordable housing in Nigeria, Paper presented at the 2nd emerging urban Africa international conference on urban housing finance in Nigeria, held at shehu yar'adua centre Abuja, October 17-19, 2007.

[4] Alemayehu, M. (1999). Industrializing Africa: Development Options and Challenges for the $21^{\text {st }}$ Century. Africa World Press, Asmara.

[5] Aribigbola, A. and Iranlowo, O. (2012). Site and services as a strategy for achieving adequate housing in Nigeria in the 21st century, International journal of humanities and social science 2, 126-132.

[6] Bourne, L.S. (1981). The Geography of Housing. Edward Arnold Publishers Limited, London. pp. 13-21. 
[7] Dayaratne, R. (2011). Reinventing traditional technologies for sustainability: contemporary earth architecture of Sri Lanka, Journal of Green building 5. 22-33.

[8] Denyer, S. (1978). African Traditional Architecture. Heine- mann Press, London. pp. 155-171.

[9] Dmochowski, Z.R. (1990). An Introduction of Nigeria Traditional Architecture, South- Eastern Nigeria, the Ibo speaking Area. Vol. III. Ethnographical in Association with National Commission of Museums and Monument. pp. 1-36.

[10] Farrelly, D. (1984). The Book of Bamboo. Sierra Club Books.

[11] Iwuagwu, B.U \& Azubuine, C. E. (2015). Global Warming Versus Green Architecture: African Experience. Proceedings of International Conference on IT, Architecture and Mechanical Engineering (ICITAME'2015) May, 2015

[12] Jolaoso, B.A. (2001). Housing and Indigenous Building Technology: An Introduction. Desi-GCA Publications, Abeokuta, Nigeria. pp. 116, 123131.

[13] Maini S. (1999). Seminar on earth architecture at Alliance Françoise De Colombo. Auroville Building Center, India

[14] Olugbenga N. T. (2001). Housing Finance in Nigeria- Need for Reengineering. Ideal Habitat Cooperative Housing Initiative.

[15] Onyike, J. (2007). An assessment of affordability of housing by public servants in Owerri, Nigeria, Journal of land use and development studies, 3, 21-34.

[16] Opaluwa, E; Paul O. and Osasona, C. (2012). Sustainability in traditional African architecture: a springboard for sustainable urban cities, Paper presented at the Sustainable Futures conference: Architecture and Urbanism in the Global South, Kampala, Uganda, 27 - 30 June 2012.

[17] RICS (2008). Compressed Earth Building Blocks. New York, USA

[18] Riza, F. V., Rahman, I. A. and Zaidi, A. M. A. (2011). Preliminary Study of Compressed Stabilized Earth Brick (CSEB). Australian Journal of Basic and Applied Sciences, 5(9) 6-12

[19] Rumana, R. (2007). Traditional House of Bangladesh: Typology of House According to Materials and Location. Virtual Conference on Sustainable Architectural Design and Urban Planning AsiaSustainabilityNet.upc.edu, September 2007

[20] Venkatarama, R. B. V., and Prasanna, K. P. (2009). Embodied energy in cement stabilised rammed earth walls. Energy and Buildings, 42(3) 380385. http://dx.doi.org/10.1016/j.enbuild.2009.10.005

[21] Yalley, P. P., \& Kwan, A. S. K. (2008). Use of Waste and Low Energy Materials in Building Block Construction, 25th Conference on Passive and Low Energy Architecture (PLEA), Dublin, 22nd to 24th October 2008. 